\title{
A Defect of Immunoregulatory T Cell Subsets in Systemic Lupus Erythematosus Patients Demonstrated with Anti-2H4 Antibody
}

\author{
Chikao Morimoto, Alfred D. Steinberg, Norman L. Letvin, Margaret Hagan, Tsutomu Takeuchi, \\ John Daley, Herb Levine, and Stuart F. Schlossman \\ Division of Tumor Immunology, Dana-Farber Cancer Institute, Department of Medicine, Harvard Medical School, Boston, \\ Massachusetts 02115; Arthritis Branch, National Institute of Arthritis, Diabetes, Digestive and Kidney Diseases, Bethesda, \\ Maryland 20205; and New England Regional Primate Research Center, Southborough, Massachusetts 01772
}

\begin{abstract}
The cell surface phenotype of peripheral blood lymphocytes (PBL) of systemic lupus erythematosus (SLE) patients was characterized with the anti-2H4 monoclonal antibody that defines the human suppressor inducer subset. The $\mathrm{T} 4^{+} 2 \mathrm{H}^{+}$population of cells has been shown to be critical for the activation of $\mathrm{T}^{+}$ suppressor cells. Patients with SLE had a markedly decreased percentage of $\mathrm{T4}^{+} 2 \mathrm{H}^{+}$cells $(13 \pm 2 \%)$ in their PBL compared with normal controls $(21 \pm 1 \%)(P<0.001)$. This reduction was greatest in patients with active SLE, especially those with renal disease. Serial analysis of patients with SLE and renal disease showed a correlation between percent positive circulating $\mathrm{T4}^{+} 2 \mathrm{H4}^{+}$cells and disease activity. Moreover, there was a significant correlation between a low percentage of $\mathrm{T}^{+} 2 \mathrm{H}^{+}$cells and decreased suppressor-inducer function in autologous mixed lymphocyte reaction-activated $\mathrm{T}^{+}$cells from SLE patients. Thus, a deficiency exists in SLE patients with active renal disease in the $\mathrm{T}^{+} 2 \mathrm{H}^{+}$suppressor-inducer $\mathrm{T}$ cell subset.
\end{abstract}

\section{Introduction}

Systemic lupus erythematosus (SLE) ${ }^{1}$ is a multisystem disease in which B cell hyperactivity results in the generation of hypergammaglobulinemia and autoantibodies (1-3). Abnormalities of suppressor $T$ cell function have been reported in patients with SLE (4-7); these could be important in the predisposition to or perpetuation of disease activity. Nevertheless, the suppressor cell defect has not been well characterized. Such a defect could result from any of several causes: a numerical or functional deficiency in the suppressor-effector cells or their precursors, a deficiency in inducers of suppressor cells, an increase in helper cell activity, or possible abnormal function of cells that interfere with suppression (contrasuppressor cells).

In earlier studies, when anti-T4 and anti-T8 monoclonal antibodies were initially defined (8-9), we found that SLE patients with multisystem involvement but without renal disease

Address reprint requests to Dr. Morimoto, Division of Tumor Immunology, Dana-Farber Cancer Institute, Boston, MA 02115. 1986.

Received for publication 11 April 1986 and in revised form 25 August

1. Abbreviations used in this paper: AMLR, autologous mixed lymphocyte reaction; FITC, fluorescein isothiocyanate; JRA, juvenile rheumatoid arthritis; SLE, systemic lupus erythematosus.

J. Clin. Invest.

(C) The American Society for Clinical Investigation, Inc.

0021-9738/87/03/0762/07 \$1.00

Volume 79, March 1987, 762-768 had a high T4/T8 ratio due to a decrease in the number of circulating T8 cells (10). In contrast, patients with SLE manifested by severe renal disease and/or thrombocytopenia had a low ratio of T4/T8 cells $(11,12)$. Nevertheless, many SLE patients had normal $\mathrm{T} 4 / \mathrm{T} 8$ ratios $(11,12)$. Thus, this ratio alone was insufficient to define a precise defect of the immunoregulatory circuit in these patients.

Previous studies demonstrated that anti-T cell antibodies found in the serum of some patients with active juvenile rheumatoid arthritis (JRA) are reactive with $\sim 40 \%$ of $\mathrm{T}^{+}$cells (13) and that the $\mathrm{T}^{+} \mathrm{JRA}^{+}$subset of $\mathrm{T}^{+}$cells which reacted with JRA anti-T cell antibodies induces suppressor function. In contrast, the $\mathrm{T4}^{+} \mathrm{JRA}^{-}$subset functions as the inducer of $\mathrm{B}$ cell Ig synthesis in the same system (14). We have recently developed a monoclonal antibody, anti-2H4 (15). This antibody reacted with $\sim 40 \%$ of $\mathrm{T}^{+}$cells but also $50-60 \%$ of $\mathrm{T}^{+}$cells. In vitro studies indicated that subpopulations of $\mathrm{T}^{+}$cells delineated by anti-2 $\mathrm{H} 4$ were functionally distinct. Whereas $\mathrm{T} 4^{+} 2 \mathrm{H} 4^{+}$cells induced suppressor function, the $\mathrm{T}^{+} 2 \mathrm{H}^{-}$subset induced helper function in both a pokeweed mitogen (PWM)-stimulated Ig synthesis $(15,16)$ and an antigen-specific antibody production system (17). Thus, anti-2H4 antibody has similar reactivity to JRA anti-T cell antibodies.

We have now utilized this antibody to characterize peripheral blood lymphocytes from SLE patients. Patients with active SLE had a significantly smaller percentage of circulating $\mathrm{T} 4^{+} 2 \mathrm{H} 4^{+}$ suppressor-inducer cells than normal individuals. In fact, patients with active SLE and renal disease had the greatest reduction in the percentage of $\mathrm{T}^{+} 2 \mathrm{H}^{+}$cells in their peripheral blood lymphocytes (PBL).

\section{Methods}

Isolation of lymphocytes. Peripheral blood mononuclear lymphocytes were separated from heparinized venous blood by Ficoll-Hypaque gradient density centrifugation (Pharmacia Fine Chemicals, Piscataway, NJ). The absolute number of peripheral lymphocytes from active SLE patients $\left(0.1-1.5 \times 10^{6} \mathrm{cells} / \mathrm{cm}^{3}\right)$ was less than that from inactive SLE patients $\left(0.5-2.0 \times 10^{6}\right.$ cells $\left./ \mathrm{cm}^{3}\right)$ or that from normal controls $\left(0.8-3.0 \times 10^{6}\right.$ cells $/ \mathrm{cm}^{3}$ ). In some experiments, peripheral blood mononuclear cells were further separated into E-rosette positive $\left(\mathrm{E}^{+}\right)$and $\mathrm{E}$-rosette negative $\left(\mathrm{E}^{-}\right)$populations with 5\% sheep erythrocytes (Microbiological Associates, Bethesda, MD) as previously described $(13,14)$. The $T$ cell population obtained was $>94 \%$ reactive with a monoclonal antibody, anti-T3, which defines an antigen present on all mature peripheral $T$ cells $(8)$. Furthermore, $\mathrm{T}^{+}$cells were isolated by anti-Ig coated plates as described (17). The purity of $\mathrm{T}^{+}$cells were $>95 \%$.

Separation of $\mathrm{T}^{+}$cells by anti-Ig coated plates. $\mathrm{T}^{+}$cells were separated into $\mathrm{T}^{+}{ }^{2} \mathrm{H}_{4}{ }^{+}$and $\mathrm{T4}^{+} 2 \mathrm{H}^{-}$subpopulations by anti-Ig coated plates as described (17). In brief, $12 \times 10^{6}$ cells were exposed to $1 \mathrm{ml}$ of anti-2 $\mathrm{H} 4$ (a 1:125 dilution of ascites) for $30 \mathrm{~min}$ at $4^{\circ} \mathrm{C}$ and then washed to remove excess antibody. $12 \times 10^{6}$ cells suspended in $3 \mathrm{ml}$ media were 
then applied to a goat anti-mouse Ig antibody-coated plastic plate (Fisher Scientific Co., Pittsburgh, PA). After 70 min of incubation at $4^{\circ} \mathrm{C}$, nonadherent and adherent populations were collected. The adherent population is consistently $95 \%$ positive with anti-2 44 antibody, and nonadherent cells are consistently $4 \%$ positive. These populations are referred to $2 \mathrm{H}^{+}$and $2 \mathrm{H}^{-}$cells, respectively.

Patients. The sample population consisted of 69 patients with SLE satisfying the diagnostic criteria of the American Rheumatism Association (18). All patients were monitored at the Arthritis Branch of the National Institute of Arthritis, Diabetes, Digestive and Kidney Diseases, Bethesda, MD. Disease activity scores were determined by two physicians on a 0-to-4 scale and averaged at the time of blood drawing on the basis of multisystem disease activity including fever, rash, arthritis, serositis, vasculitis, nephritis, and central nervous system disease. Furthermore, the disease activity of patients with renal disease was determined at the time of blood drawing whether the patients had active renal disease and/or activity in extrarenal manifestations. Seven patients were untreated, 35 patients were receiving low-dose corticosteroid therapy (5-20 mg prednisone every other day), 20 patients were receiving intermediate doses of steroids ( $20 \mathrm{mg}$ prednisone every other day to $35 \mathrm{mg}$ prednisone per day) and seven patients were receiving $>35 \mathrm{mg}$ of prednisone per day. None of the patients had received cytotoxic drugs during the preceding $6 \mathrm{mo}$ at the time of blood drawing. Blood samples were drawn at least $24 \mathrm{~h}$ after the last steroid dose. The normal control population consisted of 60 sex- and age-matched healthy individuals who had no significant illness. We judged SLE patients with activity scores $\geq 1$ to have active disease and $<1$ to have inactive disease. Patients with known renal disease were those with hematuria ( $\geq 10 \mathrm{RBC} / \mathrm{hpf}$ ), proteinuria $(\geq 1 \mathrm{~g} / 24 \mathrm{~h}$ ), RBC casts, or cellular casts either currently or in the past. In these patients, lupus renal disease was confirmed by biopsy.

Production of monoclonal antibodies. Three monoclonal antibodies termed anti-T4, anti-T8, and anti-2H4 were used in the present study. Their production and characterization are described elsewhere $(8,14)$. Anti-T4, anti-T8, and anti-2H4 are available through Coulter Immunology, Hialeah, FL. For the production of the monoclonal antibody anti-2H4, a BALB/c mouse was immunized with cells of a T lymphocyte line derived from PBL of the new world primate Aotus trivirgatus. One clone of interest secreted the monoclonal antibody termed anti-2 44. This anti-2H4 antibody reacted with $\sim 40-50 \%$ of the $\mathrm{T}^{+}$lymphocytes and $60 \%$ of $\mathrm{T}^{+}$lymphocytes. Furthermore, it reacted with non-T cells. In vitro studies indicated that subpopulations of $\mathrm{T}^{+}$cells delineated by anti-2 $\mathrm{H} 4$ were functionally distinct. $\mathrm{T} 4^{+} 2 \mathrm{H} 4^{+}$cells exhibited induction of suppressor function and the $\mathrm{T}^{+} 2 \mathrm{H}^{-}{ }^{-}$subset of lymphocytes showed helper-inducer function in a PWM-stimulated Ig synthesis system (15, 16) and an antigen-specific antibody production system (17).

Analysis of lymphocyte populations with single and two color fluorescence flow cytometry. Single color fluorescence flow cytometric analyses were performed on an Epics $\mathrm{V}$ cell sorter (Coulter Electronics, Inc.). Cells were stained with the monoclonal antibodies at a dilution of 1:500, followed by incubation with a $F\left(a^{\prime}\right)_{2}$ fragment of goat anti-mouse antibody conjugated to fluorescein isothiocyanate (FITC) (Tago Inc., Burlingame, CA). Background fluorescence reactivity was determined with control ascites fluid obtained from mice immunized with a nonsecreting hybridoma. Two color analysis was carried out on an Epics $\mathrm{V}$ cell sorter equipped with a dual laser, Argon wavelength $488 \mathrm{~nm}$ (FITC) and Krypton wavelength $568 \mathrm{~nm}$ (Texas Red), utilizing anti-T4 biotin and anti-2H4 FITC as described before (19). Binding of biotin-conjugated antibodies was detected by incubation with Texas Red (Molecular Probes Inc., Junction City, OR) conjugated to avidin (Calbiochem-Behring Corp., La Jolla, CA) or phycoerythrin-Avidin (Becton-Dickinson \& Co., Mountain View, CA) as described previously (19). For each sample, 10,000 cells were analyzed on a $\log$ fluorescence scale. Before two-color fluorescence analysis, negative as well as positive samples labeled with a single conjugated antibody or labeled by indirect fluorescence were analyzed. Negative controls for dually stained cells were obtained by staining cell samples with a biotinylated nonimmune mouse IgG antibody and Texas Red and mouse IgG antibody conjugated to FITC. All analyses were performed without knowledge of the patients' clinical status. Data are expressed as percentage of PBL rather than absolute subset cell number because of the known lymphopenia regularly seen in patients with SLE.

Suppressor function of autologous mixed lymphocyte reaction (AMLR)-activated T cells. Suppressor function of T4 cells activated by the AMLR was assessed by addition of AMLR-activated T4 cells to secondary cultures of freshly prepared PBL from a healthy single donor. Briefly, the AMLR was set up in RPMI 1640 supplemented with $10 \%$ human AB serum, $200 \mathrm{mM}$ L-glutamine, $25 \mathrm{mM}$ HEPES buffer (Microbiological Associated, Bethesda, MD), $0.5 \%$ sodium bicarbonate and $1 \%$ penicillin-streptomycin. For a primary culture of AMLR, $2 \times 10^{6}$ responder $\mathrm{T}^{+}$cells were cocultured with $2 \times 10^{6}$ irradiated $(5,000 \mathrm{Rad})$ $\mathrm{E}^{-}$cells in $4 \mathrm{ml}$ total volume of media in $25 \mathrm{~cm}^{2}$ culture flasks (Falcon Labware, Oxnard, CA). After 7 d, culture cells were layered over FicollHypaque and centrifuged at $2,000 \mathrm{rpm} \times 20 \mathrm{~min}$, and then washed three times. AMLR-activated T4 cells $\left(2 \times 10^{4}\right)$ were added to secondary cultures of $1 \times 10^{5}$ freshly isolated PBL from a healthy single donor to determine the suppressor activity of these cells. For PWM-driven IgG synthesis by PBL as a secondary culture, peripheral blood lymphocytes $\left(1 \times 10^{5}\right)$ were cultured in each well of roundbottomed 96-well microculture plates in $200 \mu \mathrm{l}$ media with $20 \%$ heat-inactivated fetal calf serum, in the presence of PWM (Gibco Laboratories, Grand Island, NY) at a final concentration of 1:100 dilution. On day 7, cultures were terminated and IgG in culture supernatants was determined by the solid-phase radioimmunoassay described before $(13,14)$.

Statistical methods. The Fisher's exact test or the two-tailed unpaired $t$ test was used as indicated to calculate $P$ values.

\section{Results}

PBL expression of T4 and 2H4 in patients with SLE and normal controls are summarized in Table I. The circulating lymphocyte population in normal individuals is composed of $54 \pm 2 \% 2 \mathrm{H}^{+}$ lymphocytes, of which only a portion are $\mathrm{T} 4^{+} 2 \mathrm{H}^{+}$suppressorinducer $T$ cells $(21 \pm 1 \%$ of total). In patients with SLE, the percentage of $2 \mathrm{H} 4$ bearing lymphocytes $(50 \pm 2 \%)$ in the peripheral blood was only marginally decreased; however, the percentage of $\mathrm{T}^{+} 2 \mathrm{H}^{+}$suppressor-inducer cells $(13 \pm 2 \%)$ in the peripheral blood was markedly decreased (Table I). Patients with active SLE had the greatest reduction in percentages of $\mathrm{T} 4^{+} 2 \mathrm{H} 4^{+}$cells (Table I). T4/T8 ratios did not significantly differ between normal controls and SLE patients.

Fig. 1 shows representative two-color profiles of peripheral blood lymphocytes coexpressing the $\mathrm{T} 4$ and $2 \mathrm{H} 4$ antigens in blood of a normal control, a patient with active SLE and one with inactive SLE. This study was done using anti-T4 biotin with Texas Red avidin and monoclonal anti-2 44 conjugated to

Table I. Cell Surface Characteristics of Lymphocytes of SLE Patients and Normal Controls

\begin{tabular}{llllllll}
\hline & & & & \multicolumn{2}{c}{ \% positive subset } & \\
\cline { 6 - 7 } Group & Number & $\begin{array}{l}\text { Sex } \\
\text { ratio }\end{array}$ & Mean age & $2 \mathrm{H}^{+}$ & $\mathrm{T}^{+} 2 \mathrm{H} 4^{+}$ & $\begin{array}{l}\text { T4/T8 } \\
\text { ratio }\end{array}$ \\
\hline & & $F / M$ & $y r$ & & & & \\
Normals & 60 & $56 / 4$ & $34(18-65)$ & $54 \pm 2^{*}$ & $21 \pm 1$ & $1.7 \pm 0.1$ \\
Total SLE & 69 & $66 / 3$ & $34(21-69)$ & $50 \pm 2$ & $13 \pm 2^{\S}$ & $1.5 \pm 0.2$ \\
$\quad$ Active SLE & 38 & $36 / 2$ & $33(23-58)$ & $46 \pm 2^{\ddagger}$ & $11 \pm 1^{\S}$ & $1.5 \pm 0.2$ \\
Inactive SLE & 31 & $30 / 1$ & $34(21-69)$ & $55 \pm 2$ & $16 \pm 2^{11}$ & $1.4 \pm 0.2$
\end{tabular}

* Results are expressed as mean $\pm \mathrm{SEM}$.

${ }^{\ddagger} P<0.01$ as compared with normal controls.

${ }^{\S} P<0.001$ as compared with normal controls.

" $P<0.05$ as compared with normal controls. 
A. Normal Control

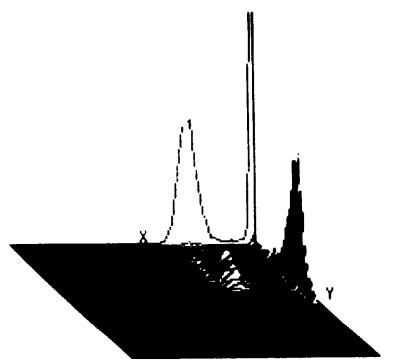

B. Active SLE

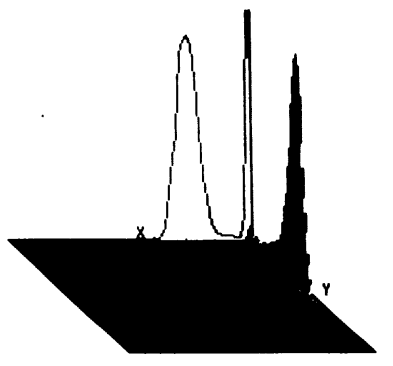

C. Inactive SLE

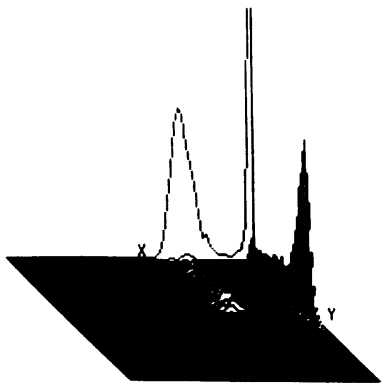

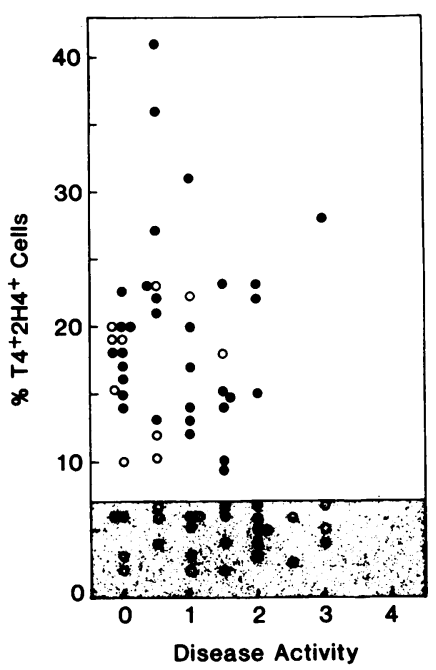

Figure 2. The relationship between the percentage of $\mathrm{T4}^{+} 2 \mathrm{H}^{+}$cells in PBL and disease activity in total SLE patients. Shaded area indicates a lower limit of two standard deviations from the mean percentage of $\mathrm{T}^{+} 2 \mathrm{H} 4^{+}$cells in the peripheral blood of normal controls (7\%). There was a significant negative correlation between percent positive $\mathrm{T}^{+} 2 \mathrm{H}^{+}$cells and disease activity $(\gamma=-0.278, P<0.05)$. (Open circles) SLE patients with known renal disease; (solid circles) SLE patients without known renal disease.

negative correlation between disease activity and percent $\mathrm{T}^{+} 2 \mathrm{H}^{+}$cells $(\gamma=-0.245, P>0.1)$.

Table II summarizes the data on the percent positive $\mathrm{T}^{+} 2 \mathrm{H}^{+}$cells in the PBL of normal controls and SLE patients with different disease types. 13 of $15(86 \%)$ SLE patients with active renal disease had a significant decrease in the percentage of $\mathrm{T}^{+} 2 \mathrm{H}^{+}$cells in their PBL compared with 7 of $23(30 \%)$ active SLE patients with non-renal disease, 5 of $13(38 \%)$ inactive SLE patients with renal disease, 2 of 18 inactive SLE patients with non-renal disease and 1 of 60 normal controls $(P<0.0001$, Fisher's exact test).

To determine whether the percent $\mathrm{T}^{+} 2 \mathrm{H} 4^{+}$circulating cells of a given patient changed with disease activity, samples were taken from seven patients on at least three occasions. Fig. 4 shows a two-color profile of PBL coexpressing the T4 and 2H4 antigens from an individual with renal disease. As shown in Fig. $4 \mathrm{~A}$, there were no detectable $\mathrm{T}^{+} 2 \mathrm{H} 4^{+}$cells in the patient's PBL at the time of initial evaluation when the disease was moderately active (activity score $1 ; \mathrm{T}^{+} 2 \mathrm{H} 4^{+}: 3.1 \%$ ). As shown in Fig. $4 \mathrm{~B}$, $\mathrm{T}^{+} 2 \mathrm{H}^{+}$cells were detectable 1 mo later at a time when the disease activity was somewhat diminished (activity score 0.5 ; $\mathrm{T}^{+} 2 \mathrm{H}^{+}: 8.5 \%$ ). More importantly, when disease activity was completely inactive 6 mo later, the percent positive $\mathrm{T}^{+} 2 \mathrm{H}^{+}$ cells returned to normal levels (activity score $0 ; \mathrm{T}^{+} 2 \mathrm{H}^{+}: 20 \%$ ) (Fig. $4 C$ ). In this case, the patient did not receive corticosteroids

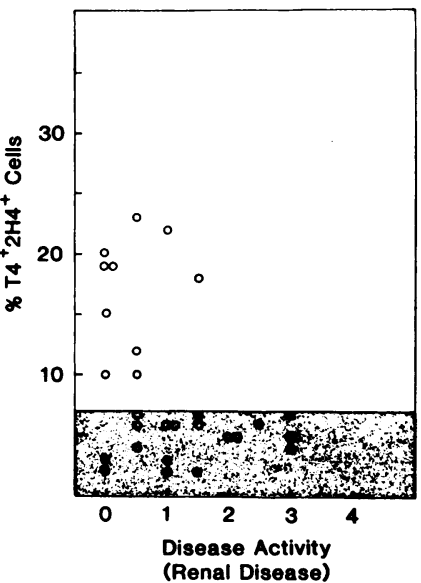

Figure 3. The relationship between the percentage of $\mathrm{T}^{+}+2 \mathrm{H}^{+}$cells and disease activity in SLE patients with known renal disease. There was a significant negative correlation between percent positive $\mathrm{T}^{+} 2 \mathrm{H}^{+}{ }^{+}$cells and disease activity $(\gamma=-0.375, P<0.05)$ 
Table II. $\mathrm{T4}^{+} 2 \mathrm{H}^{+}$Cells in SLE Patients with Different Disease Type and Activity

\begin{tabular}{|c|c|c|c|}
\hline \multirow[b]{2}{*}{ Population } & \multicolumn{3}{|c|}{$\mathrm{T}^{+} 2 \mathrm{H}^{+}$cells $(\%)$} \\
\hline & $\begin{array}{l}\text { Decreased } \\
(\leq 7)^{*}\end{array}$ & $\begin{array}{l}\text { Within normal } \\
\text { range }(>7)\end{array}$ & Decreased/Total \\
\hline \multicolumn{4}{|l|}{$\begin{array}{l}\text { Patients with } \\
\text { active SLE }\end{array}$} \\
\hline Renal disease & $13^{\ddagger}$ & 2 & $20 / 38^{5}$ \\
\hline $\begin{array}{l}\text { Non-renal } \\
\text { disease }\end{array}$ & 7 & 16 & \\
\hline \multicolumn{4}{|l|}{$\begin{array}{l}\text { Patients with } \\
\quad \text { inactive SLE }\end{array}$} \\
\hline Renal disease & 5 & 8 & $7 / 31$ \\
\hline $\begin{array}{c}\text { Non-renal } \\
\text { disease }\end{array}$ & 2 & 16 & Total SLE $27 / 69^{\| \prime}$ \\
\hline Healthy controls & 1 & 59 & $1 / 60$ \\
\hline
\end{tabular}

* Normal range is defined as two standard deviations from the mean percentage of $\mathrm{T}^{+} 2 \mathrm{H}^{+} \mathrm{T}$ cells from healthy controls and equaled $<7 \%$.

${ }^{\ddagger} P<0.0001$ (Fisher's exact test) compared with active patients with non-renal disease, inactive patients with both renal and non-renal disease and healthy controls.

${ }^{8}$ Active SLE, significantly different from inactive SLE $(P<0.025)$.

"Total SLE, significantly different from normal controls $(P<0.001)$.

before the initial evaluation of $\mathrm{T}^{+} 2 \mathrm{H} 4^{+}$cells and then received a moderate dose of corticosteroids (prednisone, $30-35 \mathrm{mg}$ every other day) until the final evaluation.

Fig. 5 shows a summary of the percent circulating $\mathrm{T}^{+} 2 \mathrm{H} 4^{+}$ cells over a period of time in 6 other patients with changing disease activity, with or without renal involvement. For the patients with renal disease (cases 1 and 2), decreased percentages of $\mathrm{T}^{+} 2 \mathrm{H} 4^{+}$cells correlated with disease activity. In some SLE patients without renal involvement (cases 3 and 4 ), the percent positive $\mathrm{T}^{+} 2 \mathrm{H}^{+}$cells did not always correlate with the disease activity over time. Others with nonrenal SLE (cases 5 and 6) did demonstrate a negative association between the percent positive $\mathrm{T}^{+} 2 \mathrm{H} 4^{+}$cells and disease activity.

We recently demonstrated that $\mathrm{T}^{+}$cells activated in AMLR can function as suppressor-inducer cells in a system involving PWM-driven IgG synthesis (20). Furthermore, the $\mathrm{T}^{+} 2 \mathrm{H}^{+}$ subset of cells proliferated maximally in AMLR and the suppressor-inducer activity of $\mathrm{T}^{+}$cells generated in the AMLR

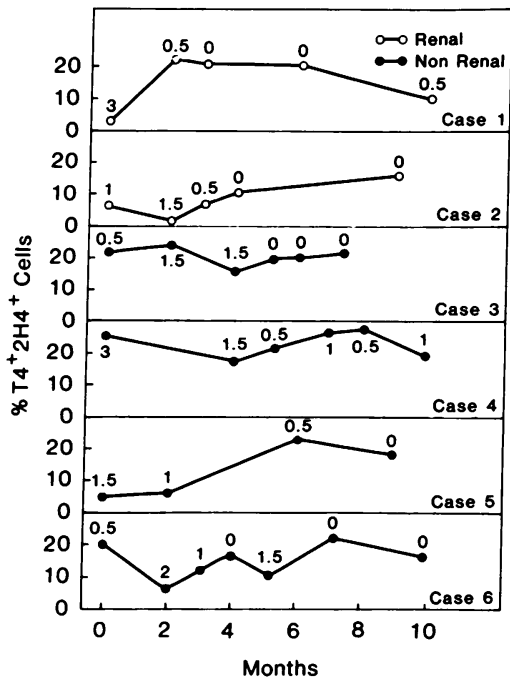

Figure 5. The summary of the percent $\mathrm{T}^{+} 2 \mathrm{H}^{+}$ cells over a period of time in six other patients with changing disease activity. The percentage of $\mathrm{T}^{+} 2 \mathrm{H} 4^{+}$ cells is shown in the $y$ axis over time. Numerals adjacent to the data points represent the SLE disease activity score at that time.

response was attributable to an activated $\mathrm{T} 4^{+} 2 \mathrm{H} 4^{+}$suppressorinducer subset (20). To ascertain these points, $\mathrm{T}^{+}, \mathrm{T}^{+} 2 \mathrm{H} 4^{+}$, or $\mathrm{T}^{+} 2 \mathrm{H}^{-}$cells from normal individuals were triggered with autologous non- $T$ cells for $7 \mathrm{~d}$ and added to freshly isolated PBL from a healthy single donor to assess their effect on PWMdriven IgG synthesis. As shown in Table III, AMLR-activated $\mathrm{T}^{+}$and $\mathrm{T} 4^{+} 2 \mathrm{H} 4^{+}$cells had a strong suppressor activity in a dose-dependent fashion. In contrast, AMLR-activated $\mathrm{T} 4^{+} 2 \mathrm{H} 4^{+}$ cells had no such effect. It should be noted that there was no suppression observed when AMLR-activated $\mathrm{T}^{+}{ }^{+}$cells were added to $\mathrm{B}+\mathrm{T} 4$ cells with $\mathrm{PWM}$ in the absence of $\mathrm{T}^{+}$cells, thus indicating that these cells functioned as suppressor inducers (20). Therefore, these results reconfirmed that AMLR-activated $\mathrm{T}^{+} 2 \mathrm{H}^{+}$cells but not $\mathrm{T}^{+} 2 \mathrm{H}^{-}$cells showed the suppressorinducer activity.

Next, to determine whether the decreased percent of $\mathrm{T}^{+} 2 \mathrm{H}^{+}$suppressor-inducer cells was associated with the defect of generating suppressor activity by AMLR-activated T4 cells, we studied the relationships between percent $\mathrm{T} 4^{+} 2 \mathrm{H} 4^{+}$cells and percent suppression by AMLR-activated T4 cells from SLE patients with known renal disease. To examine suppressor activity, T4 cells from patients with SLE were triggered in AMLR for 7 $\mathrm{d}$ and then AMLR-activated T4 cells $\left(2 \times 10^{4}\right)$ were added to 1 $\times 10^{5}$ freshly isolated PBL from a healthy single donor to assess their effect on PWM-driven IgG synthesis. As shown in Fig. 6, 15 patients with SLE were studied in this fashion and a significant correlation between a low percentage of $\mathrm{T} 4^{+} 2 \mathrm{H} 4^{+}$cells and a decreased percent suppression of PWM-driven IgG synthesis by
A

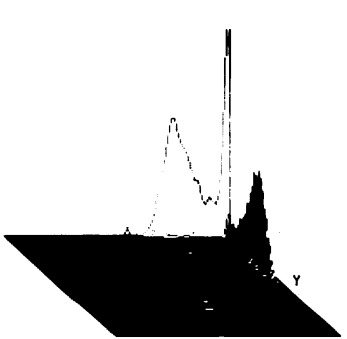

Disease

Activity

Time
B

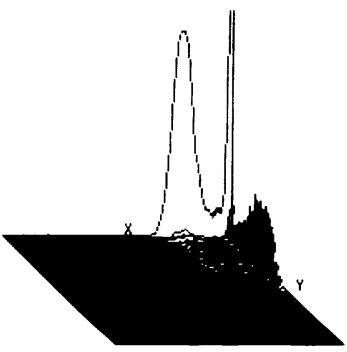

(0.5)

Month Later

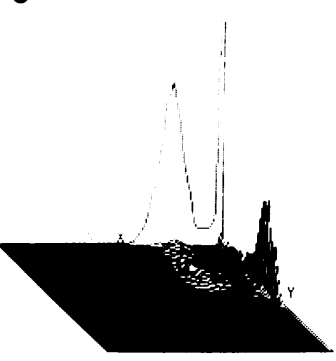

(0)

6 Month Later
Figure 4. Two-color profile of PBL coexpressing the $\mathrm{T} 4$ and $2 \mathrm{H} 4$ antigens from a SLE patient with renal disease changed with disease activity. $L o g$ red fluorescence (the $\mathrm{T} 4^{+}$subset) is shown along the $x$ axis and $\log$ green fluorescence (the $2 \mathrm{H}^{+}$subset) along $y$ axis. Cell number is represented on the vertical axis. 
Table III. Effect of AMLR-activated Subsets of T4 Cells on PWM-driven IgG Synthesis

\begin{tabular}{|c|c|c|c|c|}
\hline \multirow[b]{2}{*}{ Regulator cells* } & & \multicolumn{3}{|l|}{ IgG (ng/ml) } \\
\hline & & Exp. 1 & Exp. 2 & Exp. 3 \\
\hline - & & $9200 \pm 200^{\ddagger}$ & $8800 \pm 600$ & $7600 \pm 320$ \\
\hline \multirow[t]{3}{*}{ AMLR T4 } & $5 \times 10^{3}$ & $8300 \pm 880(9)^{8}$ & $8080 \pm 480(8)$ & $6800 \pm 960(11)$ \\
\hline & $1 \times 10^{4}$ & $5600 \pm 250(45)$ & $5920 \pm 400(33)$ & $4400 \pm 560(42)$ \\
\hline & $2 \times 10^{4}$ & $3640 \pm 310(71)$ & $3200 \pm 240(64)$ & $3640 \pm 480(52)$ \\
\hline \multirow[t]{3}{*}{ AMLR T4 $4^{+} 2 \mathrm{H}^{+}$} & $5 \times 10^{3}$ & $4040 \pm 460(56)$ & $2560 \pm 320(71)$ & $2560 \pm 240(66)$ \\
\hline & $1 \times 10^{4}$ & $830 \pm 60(91)$ & $1920 \pm 400(78)$ & $960 \pm 40$ (87) \\
\hline & $2 \times 10^{4}$ & $550 \pm 80(94)$ & $800 \pm 40(91)$ & $240 \pm 40(97)$ \\
\hline \multirow[t]{3}{*}{ AMLR $\mathrm{T}^{+} 2 \mathrm{H}^{-}$} & $5 \times 10^{3}$ & $9500 \pm 680(-3)$ & $8160 \pm 1240(7)$ & $7200 \pm 560(5)$ \\
\hline & $1 \times 10^{4}$ & $9700 \pm 510(-5)$ & $8960 \pm 720(-2)$ & $7600 \pm 480(0)$ \\
\hline & $2 \times 10^{4}$ & $9850 \pm 540(-7)$ & $9600 \pm 1600(-9)$ & $8200 \pm 960(-8)$ \\
\hline
\end{tabular}

\footnotetext{
* Increasing numbers of 7-d AMLR-activated subsets of T4 cells in healthy individuals $\left(5 \times 10^{3}-2 \times 10^{4}\right)$ were added to freshly isolated PBL from a single healthy donor with PWM to assess their immunoregulatory role. ${ }^{\ddagger}$ Results were expressed as mean of triplicate samples \pm SD. ${ }^{8}$ Parenthesis showed percent suppression calculated as follows: $1-$ (observed IgG/IgG in no regulatory cells) $\times 100$.
}

AMLR-activated T4 cells from SLE patients was found $(\gamma=0.90$, $P<0.001)$. These results further support the notion that the $\mathrm{T}^{+} 2 \mathrm{H} 4^{+}$cells may play an important role in generating suppressor-inducer activity in vivo.

To exclude the possibility that the low percent of $\mathrm{T}^{+} 2 \mathrm{H}^{+}$ cells in patients with active renal disease may be due to the presence of autoantibodies bound to cell membrane antigens interfering with anti-2H4 staining, we selected patients who had anti-T cell antibodies in their sera as previously described (21). Then $T$ cells from normal donors were incubated with these sera for $1 \mathrm{~h}$ at $4^{\circ} \mathrm{C}$, and after extensive washing these cells were stained with anti-2H4 antibody or anti-T4 antibody and goat anti-mouse Ig FITC. As shown in Table IV, incubation of T cells with SLE sera did not interfere with anti-2H4 and anti-T4 staining of $\mathrm{T}$ cells. Thus, these results indicated that the above possibility was unlikely.

\section{Discussion}

Anti-2H4 reacts with $\sim 40-50 \%$ of $\mathrm{T}^{+}$lymphocytes and 50 $60 \%$ of $\mathrm{T}^{+}$lymphocytes in man (15). In vitro studies indicated that the $\mathrm{T}^{+} 2 \mathrm{H}^{+}$subset of lymphocytes exhibited the inducer of suppressor function similar to that previously described as

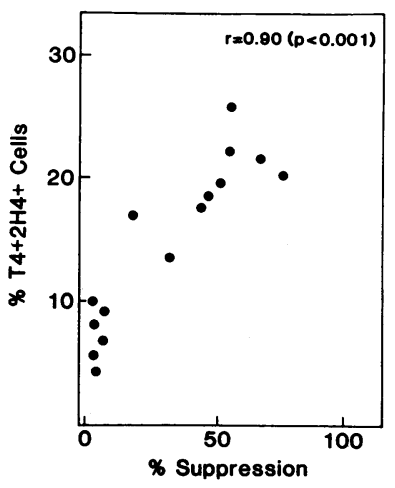

Figure 6. The relationship between the percent of $\mathrm{T}^{+} 2 \mathrm{H} 4^{+}$cells and the percent suppression of PWMdriven synthesis by AMLR-activated cells from patients with SLE. Percent suppression was calculated as described in Table III. the $\mathrm{T}^{+}{ }^{+} \mathrm{JRA}^{+}$subset $(13,14)$ that induces or activates $\mathrm{T}^{+}$cells to exert suppressor function. In contrast, the $\mathrm{T}^{+} 2 \mathrm{H}^{-}$subset of lymphocytes induced helper function in both a PWM-stimulated Ig synthesis $(15,16)$ and an antigen-specific antibody production system (17). Furthermore, the $\mathrm{T} 4^{+} 2 \mathrm{H}^{+}$subset proliferates maximally in response to autologous non- $\mathrm{T}$ cells but poorly to soluble antigen stimulation. The $\mathrm{T}^{+} 2 \mathrm{H}^{-}{ }^{-}$subset, in contrast, proliferates relatively poorly to autologous non- $T$ cells but well to soluble antigen stimulation.

The present study utilizes the anti-2H4 monoclonal antibody to characterize the cell surface phenotype of peripheral blood lymphocytes in SLE patients with varying disease activity and in subgroups of patients with and without known renal disease.

Table IV. Anti-T Cell Antibodies in Patients with SLE Did Not Interfere with Anti-2H4 Staining

\begin{tabular}{lll}
\hline & \multicolumn{2}{l}{$\begin{array}{l}\text { Staining with monoclonal } \\
\text { antibodies }\end{array}$} \\
\cline { 2 - 3 } & Anti-T4 & Anti-2H4 \\
\hline & $\%$ & $\%$ \\
Exp. 1 & & \\
T cont cells* & 64 & 51 \\
T cells incubated with serum A & 62 & 53 \\
Exp. 2 & & \\
T cont cells & 69 & 46 \\
T cells incubated with SLE serum B & 68 & 45 \\
Exp. 3 & & \\
T cont cells & 57 & 44 \\
T cells incubated with SLE serum C & 59 & 43 \\
\hline
\end{tabular}

* T cont cells were incubated with normal human AB serum for $1 \mathrm{~h}$ at $4^{\circ} \mathrm{C}$

${ }^{\ddagger} \mathrm{T}$ cells were incubated with SLE serum who had anti-T cell antibodies for $1 \mathrm{~h}$ at $4^{\circ} \mathrm{C}$. 
As a group, patients with SLE had a significant reduction in the $\mathrm{T} 4^{+} 2 \mathrm{H}^{+}$percent of their PBL. The greatest reduction was in patients with known renal disease and active SLE. There was a significant decrease in the percent $\mathrm{T}^{+} 2 \mathrm{H}^{+}$cells in 13 of 15 active patients with known renal disease. Because patients with active SLE have a decrease in circulating lymphocytes, the absolute reduction in number of $\mathrm{T}^{+} 2 \mathrm{H}^{+}{ }^{+}$cells is even more marked. It should be noted that the anti-2H4 antibody not only reacts with a part of $\mathrm{T}^{+}$cells but also reacts with a part of $\mathrm{T}^{+}$ cells and non-T cells. Although in the present study we showed that there was the significant decreased percent of $\mathrm{T}^{+} 2 \mathrm{H} 4^{+}$cells in SLE patients with active renal disease, decreased percent of $\mathrm{T}^{+} 2 \mathrm{H} 4^{+}$cells in such patients was also observed (data not shown). Further studies were now in progress to determine the functional role of $\mathrm{T}^{+} 2 \mathrm{H}^{+}$cells and $2 \mathrm{H} 4$ bearing non-T cells and their significance to autoimmune diseases such as SLE.

In previous studies, SLE patients with multisystem involvement but without renal disease often had a high T4/T8 ratio due to a decrease in the number of $\mathrm{T}^{+}(10-12)$. In contrast, patients with SLE manifested by severe renal disease and/or thrombocytopenia tended to have a low T4/T8 ratio due to a decreased percent of $\mathrm{T}^{+}$inducer cells and increased percent of $\mathrm{T}^{+}$cells $(11,12)$. Nevertheless, many patients with SLE had a normal T4/T8 ratio and shared some clinical features of the other two groups (12). Thus, the ratio itself was insufficient to define a precise defect of the immunoregulatory circuit in most SLE patients. The anti-2H4 antibody adds another parameter to the analysis of human regulatory cells that may prove useful for the characterization of the cellular basis for the defects in patients with autoimmune diseases. Furthermore, the present study shows that there was a significant correlation between a low percent of $\mathrm{T}^{+} 2 \mathrm{H} 4^{+}$cells and a decreased percent of PWMdriven IgG synthesis by AMLR-activated $\mathrm{T}^{+}$cells from SLE patients.

Because patients with SLE manifest lymphopenia (22-24) and impaired $T$ cell function (25-28), a relationship between the anti-lymphocyte antibodies and this impaired $T$ cell function has long been sought. The precise mechanism of loss of circulating $\mathrm{T} 4^{+} 2 \mathrm{H} 4^{+}$cells in patients with active renal disease is not clear at the present time. We have previously shown, however, that many patients with SLE have anti-T cell antibodies in their sera that react with a functional $\mathrm{T}^{+}$suppressor-inducer subset of lymphocytes (21). Thus, sera of the patients with a loss of $\mathrm{T} 4^{+} 2 \mathrm{H}^{+}$cells could have anti- $\mathrm{T}$ cell antibodies that are reactive with the $\mathrm{T}^{+} 2 \mathrm{H}^{+}$subset of cells and play some role in their eimination from the circulation.

Although some patients with non-renal disease had a selective decrease in percent of $\mathrm{T}^{+} 2 \mathrm{H}^{+}$cells, many other patients had normal percentage of $\mathrm{T}^{+} 2 \mathrm{H}^{+}$cells. The defects in immunoregulatory circuits in these individuals might include abnormal $\mathrm{T}^{+}$suppressor cells, B cells, monocytes, or possibly functional abnormalities.

A selective loss of $\mathrm{T4}^{+} 2 \mathrm{H}^{+}$cells is not only limited to patients with active SLE and renal disease. Our recent studies indicate that many patients with progressive multiple sclerosis have a selective decrease in the percentage of circulating $\mathrm{T}^{+} 2 \mathrm{H}^{+}$ cells (C. Morimoto et al., unpublished data). In contrast, there are normal numbers of circulating $\mathrm{T}^{+} 2 \mathrm{H}^{+}$cells in patients with other neurological diseases. Thus, the present study strengthens the potential importance of the anti-2 44 antibody in studying immunoregulatory defects in autoimmune diseases.

\section{Acknowledgments}

The authors would like to thank Howard M. Brown for his skillful technical assistance. We would also like to thank Elizabeth $\mathrm{H}$. Swinton for excellent secretarial assistance.

This work was supported in part by National Institutes of Health grants A1-12069, A1-20729, RR00168, CA-19589, and AM-33713.

\section{References}

1. Budman, D. R., E. B. Merchant, A. D. Steinberg, D. Doft, M. E. Gershwin, E. Lizzio, and J. P. Reeves. 1977. Increased spontaneous activity of antibody-forming cells in the peripheral blood of patients with active SLE. Arthritis Rheum. 20:829-833.

2. Morimoto, C., T. Abe, M. Hara, and M. Homma. 1977. In vitro TNP-specific antibody formation by peripheral lymphocytes from patients with systemic lupus erythematosus. Scand. J. Immunol. 6:575579.

3. Koffler, D., P. H. Schur, and H. G. Kunkel. 1967. Immunological studies concerning the nephritis of systemic lupus erythematosus. J. Exp. Med. 126:607-623.

4. Abdou, N. I., A. Sagawa, E. Pascal, J. Hervert, and S. Sadeghee. 1976. Suppressor T cell abnormality in idopathic systemic lupus erythematosus. Clin. Immunol. Immunopathol. 6:192-199.

5. Bresnihan, B., and H. E. Jasin. 1977. Suppressor function of peripheral blood mononuclear cells in normal individuals and patients with systemic lupus erythematosus. J. Clin. Invest. 59:106-116.

6. Morimoto, C. 1978. Loss of suppressor T lymphocyte function in patients with SLE. Clin. Exp. Immunol. 32:125-133.

7. Sakane, T., A. D. Steinberg, and I. Green. 1978. Studies of immune function of patients with SLE. I. Dysfunction of suppressor T cell activity related to impaired generation of, rather than response to, suppressor cells. Arthritis Rheum. 21:657-664.

8. Reinherz, E. L., and S. F. Schlossman. 1980. The differentiation and function of human T lymphocytes. Cell. 19:821-827.

9. Ledbetter, J. A., R. L. Evans, M. Lipinski, C. Cunningham-Rundles, R. A. Good, and L. A. Herzenberg. 1981. Evolutionary conservation of surface molecules that distinguish $\mathrm{T}$ lymphocyte helper/inducer and cytotoxic/suppressor subpopulations in mouse and man. J. Exp. Med. 153:310-323.

10. Morimoto, C., E. L. Reinherz, S. F. Schlossman, P. H. Schur, J. A. Mills, and S. D. Steinberg. 1980. Alteration of immunoregulatory $\mathrm{T}$ cell subsets in active SLE. J. Clin. Invest. 66:1171-1174.

11. Smolen, J. S., T. M. Chused, W. M. Leiserson, J. P. Reeves, D. W. Alling, and A. D. Steinberg. 1982. Heterogeneity of immunoregulatory $\mathrm{T}$ cell subsets in systemic lupus erythematosus. Am. J. Med. 727: 783-790.

12. Smolen, J. S., C. Morimoto, A. D. Steinberg, A. Wolf, S. F. Schlossman, R. T. Steinberg, E. Penne, E. L. Reinherz, M. Rerchlin, and T. M. Chused. 1985. Systemic lupus erthematosus: delineation of subpopulations by clinical, serologic and T cell marker analysis. Am. J. Med. Sci. 289:139-147.

13. Morimoto, C., E. L. Reinherz, Y. Borel, E. Mantzouranis, A. D. Steinberg, and S. F. Schlossman. 1981. An autoantibody to an immunoregulatory inducer population in patients with JRA. J. Clin. Invest. 67:753-761.

14. Morimoto, C., E. L. Reinherz, Y. Borel, and S. F. Schlossman. 1983. Direct demonstration of human suppressor inducer subset defined by JRA anti-T cell antibodies. J. Immunol. 130:157-161.

15. Morimoto, C., N. L. Letvin, J. A. Distaso, W. R. Aldrich, and S. F. Schlossman. 1985. The isolation and characterization of the human suppressor inducer T cell subset. J. Immunol. 134:1508-1515.

16. Letvin, N. L., C. Morimoto, W. R. Aldrich, and S. F. Schlossman. 1985. Definition of the T-lymphocyte inducer of suppression in primates using a monoclonal antibody. Cell. Immunol. 94:360-368.

17. Morimoto, C., N. L. Letvin, J. A. Distaso, H. M. Brown, and S. F. Schlossman. 1986. The cellular basis for the induction of antigen specific T8 suppressor cells. Eur. J. Immunol. 16:198-204. 
18. Cohen, A. S., W. E. Reynolds, E. C. Franklin, J. P. Kulka, M. W. Ropes, L. E. Shulman, and S. L. Wallace. 1971. Preliminary criteria for classification of systemic lupus erythematosus. Bull. Rheum. Dis. 21:643-648.

19. Blue, M. L., J. F. Daley, H. Levine, and S. F. Schlossman. 1985. Co-expression of T4 and T8 on peripheral blood T cells demonstrated by two-color fluorescence flow cytometry. J. Immunol. 134:2281-2286.

20. Takeuchi, T., S. F. Schlossman, and C. Morimoto. 1986. Immunoregulatory function of T4 cells after activation in autologous mixed lymphocyte reaction. Arthritis Rheum. 295(Suppl.):20.

21. Morimoto, C., E. L. Reinherz, J. A. Distaso, A. D. Steinberg, and S. F. Schlossman. 1984. Relationship between SLE T cell subsets, anti-T cell antibodies and T cell function. J. Clin. Invest. 73:689-700.

22. Messner, P. P., F. D. Lindstrom, and R. C. Williams, Jr. 1973. Peripheral blood lymphocyte cell surface markers during the course of systemic lupus erythematosus. J. Clin. Invest. 57:604-614.

23. Scheinberg, M. A., and E. S. Cathcart. 1974. B cell and T cell lymphopenia in systemic lupus erythematosus. Cell. Immunol. 12:309314.

24. Glinski, W., M. E. Gershwin, D. R. Budman, and A. D. Steinberg. 1976. Study of lymphocyte subpopulations in normal humans and patients with systemic lupus erythematosus by fractionation of peripheral blood lymphocytes on a discontinuous Ficoll gradient. Clin. Exp. Immunol. 26:228-238.

25. Horwitz, D. A. 1972. Impaired delayed hypersensitivity in systemic lupus erythematosus. Arthritis Rheum. 15:353-359.

26. Hahn, B. H., M. K. Bagby, and C. K. Osterland. 1973. Abnormalities of delayed hypersensitivity in systemic lupus erythematosus. Am. J. Med. 53:25-31.

27. Suciu-Foca, N., J. A. Buda, T. Thiem, and K. Reemtsma. 1974. Impaired responsiveness of lymphocytes in patients with systemic lupus erythematosus. Clin. Exp. Immunol. 18:207-217.

28. Rosenthal, C. J., and E. C. Franklin. 1975. Depression of cellular mediated immunity in systemic lupus erythematosus. Relation to disease activity. Arthritis Rheum. 18:207-217. 